\title{
Retreat of mountain glaciers of northern Eurasia since the Little Ice Age maximum
}

\author{
Olga N. Solomina \\ Institute of Geography, Russian Academy of Sciences, 29 Staromonetny Street, Moscow 109017, Russia
}

\begin{abstract}
Analysis of aerial photographs of about 1000 glaciers located in the mountain ranges of the former Soviet Union - Caucasus, Polar Urals, Pamir-Alay, Tien Shan, Altay, Kodar, Cherskiy range, Suntar-Khayata, Koryakskoye Nagorye, Kamchatka shows that variations in the magnitude of glacier retreat since the Little Ice Age maximum are significant and probably connected to climatic continentality. On average, the scale of glacier shrinkage is much smaller in continental Siberia than in central Asia and along the Pacific margins.
\end{abstract}

\section{INTRODUCTION}

The magnitude of glacier variations is one of the most important indicators of global change. Although the interpretation of the climatic causes is very complex, glacier variations are proof of large-scale events like the Little Ice Age (LIA) or modern global warming.

The positions of the LIA moraines are often used as a reference point to estimate the magnitude of past glacier variations including recent variations and those further back in time into the Holocene and Late Pleistocene (Furrer and others, 1987; Grove, 1988). The well-known moraines deposited around the 1850s in the Alps are used for this purpose: two inventories include detailed information about glacier size in the mid-19th century, in the 1920s and in 1969 and 1975, respectively, for Austria (Gross, 1987) and Switzerland (Maisch, 1992).

The data on LIA glaciers in the mountainous areas of the former Soviet Union (FSU) are insufficient to allow this kind of detailed reconstruction. The first regular descriptions and maps of glaciers date from the 1880s-1910s in the Caucasus (Podozersky, 1911) and from the beginning of the 20th century in central Asia (Korzhenevskiy, 1930) and in Altay (Sapozhnikov, 1926). In some regions of northeast Siberia the first glaciological expeditions were conducted only in the 1950s in connection with the International Geophysical Year (Preobrazhenskiy, 1960; Koreysha, 1991). The lack of historical information can be partially offset by moraine dates obtained by lichenometry in combination with radiocarbon and treering analysis. These dates are much less accurate than those obtained from historical descriptions, but allow us to determine the position of LIA moraines in general.

The aim of this paper is to estimate the magnitude of glacier retreat from the LIA maximum to the second half of the 20th century in the FSU, on the basis of aerial photographs and chronosequences of vegetation development on Holocene moraines. Although very general, these data can reveal global change trends on a century scale in remote and poorly studied areas with short and rare meteorological and glaciological datasets.

\section{MATERIALS AND METHODS}

An inventory containing 998 glaciers in the Caucasus, PamirAlay, Tien Shan, Altay, Kodar, Suntar-Khayata, Cherskiy range, Koryakskoye Nagorye and Kamchatka was assembled by M. I. Bodnya, G. M. Varnakova, T. N. Pokrovskaya, E. S. Filatov, Ya. D. Muraviev, V. N. Mikhalenko and O. N. Solomina (principal investigator). The data are available in numerical form as an appendix to Solomina (1997).

The number of glaciers included in the inventory for each region is proportional to the total number of glaciers in the region (Fig. 1). The distance from the largest fresh-looking end moraine, which was covered by no or only sparse vegetation and thus could be distinguished from older moraines by a lighter colour on aerial photographs, to the front of the glacier, and the elevation of the foot of this moraine were measured using available black-and-white aerial photographs of 1:30 000 to $1: 70000$ scale from the 1950 s-80s together with maps of 1:100000, 1:50000, and 1:25000 scale. First we

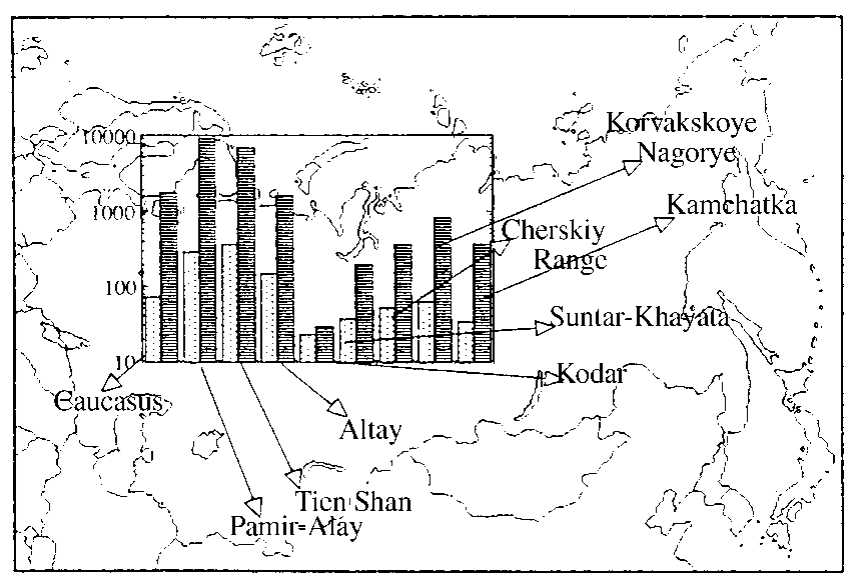

Fig. 1. Location of the regions included in the inventory. Shaded columns: number of glaciers in the mountain region; white columns: number of glaciers included in the inventory (log-scale). 


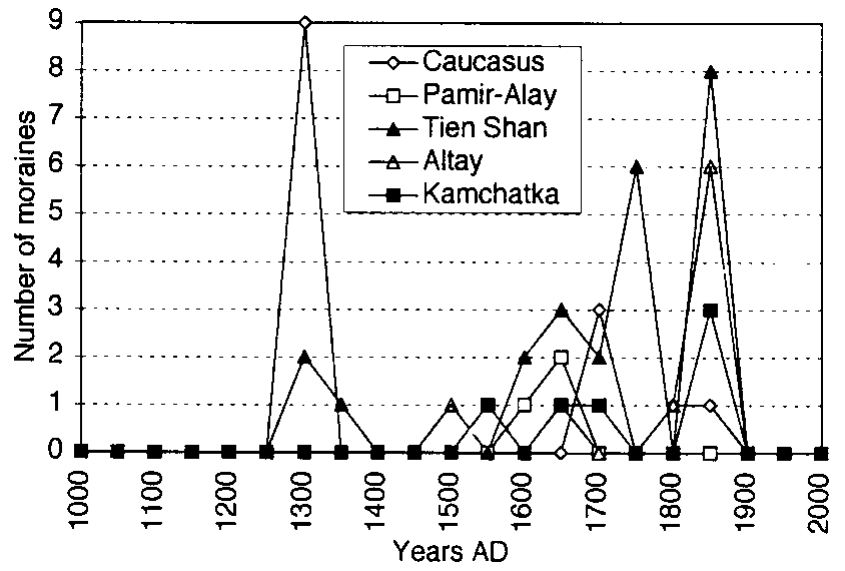

Fig. 2. Moraines of the LIA maximum dated by lichenometry in the Caucasus (Serebryannyy and others, 1984), PamirAlay, Tien Shan, Altay and Kamchatka (Solomina, 1997).

identified the LIA moraines on aerial photographs, then the margins of LIA glacier snouts were marked on the maps. The inventory also contains the elevation of the beginning of lateral moraines, medial moraines and corresponding nunataks, but these data are not discussed in this paper. The Glacier Inventory of the USSR (Akademii Nauk SSSR 196982) was the source of information for the length $(L)$ of the glacier, its highest point $\left(H_{\mathrm{h}}\right)$ and terminus elevation $\left(H_{\mathrm{f}}\right)$. Where possible we used the most recent aerial photographs and maps of the largest scale. When selecting the glaciers, we took into consideration the availability of maps and summer aerial photographs, and the preservation of the presumed LIA end moraines. All glaciers were included where lichenometric, tree-ring or radiocarbon data had previously been obtained (see Solomina, 1997). We tried to include all types of glaciers present in a mountainous area.

The accuracy for the definitions of the location of the moraines is $\pm 10 \mathrm{~m}$ for maps of 1:25000 scale (Tien Shan, some regions of Pamir-Alay, Caucasus and Kamchatka), and $\pm 50 \mathrm{~m}$ for areas where only 1:100000 maps were available (Siberia). The date of the "actual" position of glacier fronts considered here ranges from the 1950s to the 1980s due to the dates of maps and aerial photographs available for these regions. The data on glacier retreat obtained by Panov (1993) for the Caucasus, and by Revyakin and Mukhametov (1986) for the Altay, and a large set of historical descriptions of individual glaciers were analyzed to specify the age of moraines and the former positions of the glacier fronts.

The degree of primary succession combined with lichenometry was used to outline the terrains exposed by glacier retreat after the LIA maximum. Lichenometry shows that everywhere in the mountains of the FSU, except the Caucasus, the moraines deposited from the 17 th to the mid-19th century are not completely covered by vegetation and therefore could be recognized on aerial photographs.

Figure 2 shows lichenometric dates of the most reliably dated outermost LIA moraines, selected from a large dataset of 80 moraines. The complete list is available in Solomina (1997). According to lichenometry in the Tien Shan, PamirAlay, Polar Urals, Altay and Kamchatka, the maximum glacier advances of the last millennium occurred between the 17 th and mid-19th centuries and the magnitudes of several advances that occurred in the 17 th, 18th and mid19th centuries were approximately identical (Solomina, 1997). Only in the Caucasus did the 13th-century advance considerably surpass the later advances, and the difference in magnitude of glacier fluctuations between the 13th and 19 th centuries is too big to be overlooked, even for our rather rough estimations (Serebryannyy and others, 1984). According to Serebryannyy and others (1984), the 70-100 year old moraines are almost completely covered by vegetation and therefore they are the last ones to be distinguished from older moraines on aerial photographs. For this reason the estimates of glacier retreat given here for this area concern the stages of the 1880s and 1900s. Since the advances between the 17 th and mid-19th centuries were larger, these estimates should be regarded as minimum values for the LIA.

Up to now no data exist on the age of moraines in SuntarKhayata, Kodar, the Cherskiy range and other territories of northeast Siberia. However, the snouts of these glaciers are bordered by fresh-looking moraines. Severe climate and permafrost contribute to a slow moraine colonization. Thus, comparing these moraines with those of known age in adjacent regions such as the Altay mountains, one could suggest that these moraines were formed within the last several hundred years; they can be considered as LIA moraines. The tree-ring reconstruction covering a broad area near the northern timberline (west-east transect, $42-152^{\circ} \mathrm{E}$ ) shows two main thermal minima, at the end of the 17 th century and from the end of the 18th to the first half of the 19th century, that probably triggered the glacier advances in northeast Siberia (Schweingruber and Briffa, 1996).

Table 1. Descriptive statistics of length change $(\Delta L)$ and change in terminus height $(\Delta H)$ of Eurasian glaciers since the LIA maximum

$\begin{array}{llll}\text { Mountain area Number Min. Max. Median Mean } & \text { Std Skew-Kurtosis } \\ & \text { ofobser- } & \text { dev. ness } \\ & \text { vations }\end{array}$

$\mathrm{m} \quad \mathrm{m} \quad \mathrm{m} \quad \mathrm{m}$

\begin{tabular}{lrrrrrrrr}
\hline $\begin{array}{l}\text { Caucasus (end of } \\
\quad \text { 19th-beg. of } \\
\quad \text { 20th century) }\end{array}$ & 70 & 150 & 2800 & 480 & 611 & 471 & 2.43 & 8.11 \\
$\begin{array}{l}\text { Pamir-Alay } \\
\quad \text { non-surging }\end{array}$ & 231 & 30 & 3600 & 500 & 706 & 577 & 1.81 & 4.19 \\
$\begin{array}{l}\text { Pamir-Alay } \\
\quad \text { surging }\end{array}$ & 32 & 100 & 3600 & 1000 & 1330 & 1001 & 1.05 & 0.22 \\
$\quad \begin{array}{l}\text { Tien Shan } \\
\text { Altay }\end{array}$ & 341 & 200 & 4200 & 825 & 976 & 561 & 1.45 & 3.5 \\
Kodar & 120 & 90 & 2300 & 458 & 558 & 396 & 2.02 & 4.53 \\
Suntar-Khayata & 23 & 0 & 500 & 100 & 130 & 143 & 1.36 & 1.21 \\
$\quad \begin{array}{l}\text { Cherskiy range } \\
\text { Koryakskoye }\end{array}$ & 52 & 0 & 700 & 200 & 259 & 199 & 0.45 & -0.82 \\
$\quad$ Nagorye & 63 & 0 & 2000 & 600 & 686 & 537 & 0.46 & -0.6 \\
Kamchatka & 29 & 0 & 1400 & 600 & 602 & 353 & 0.41 & -0.66
\end{tabular}

$\Delta H$

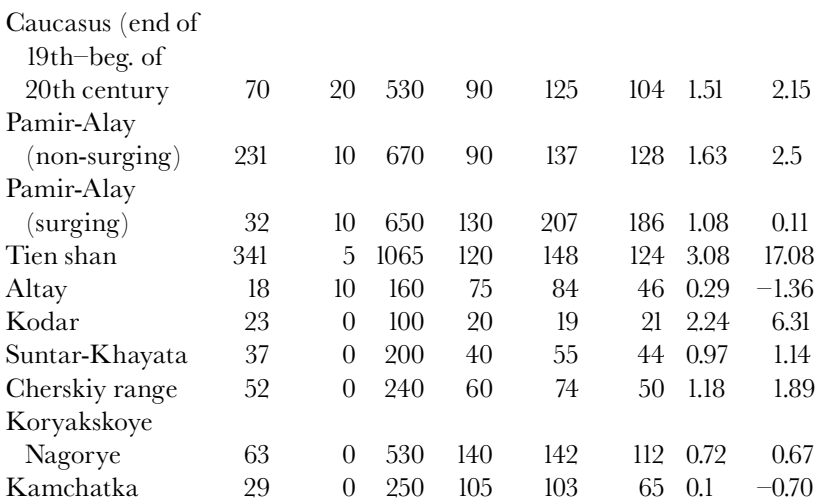




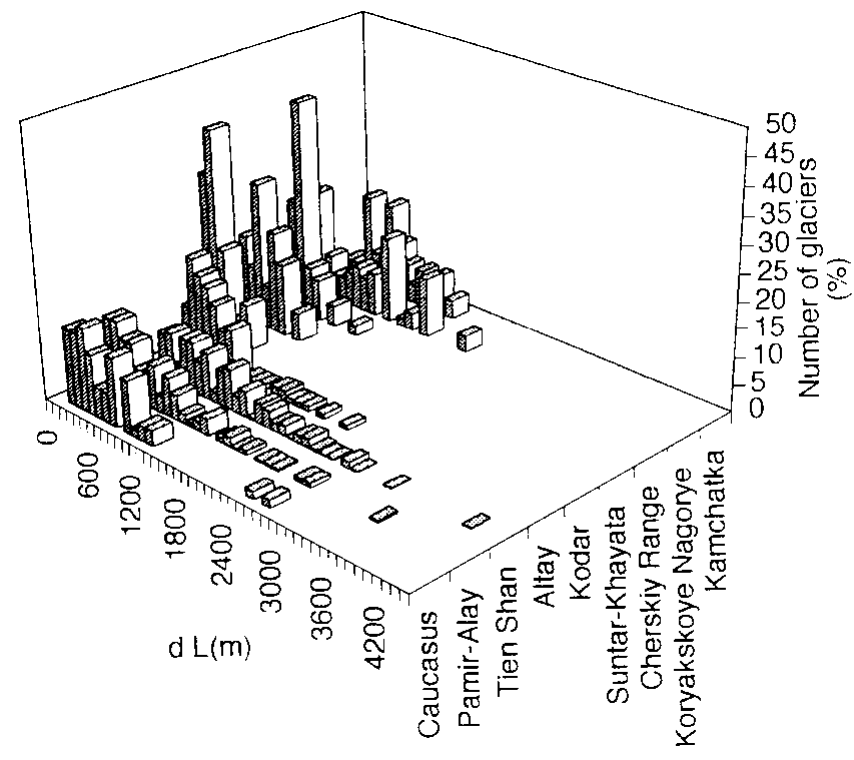

Fig. 3. Length change of glaciers since the LIA maximum (from the 17th to the mid-19th century). For the Caucasus the length loss is estimated since the end of the 19th or the beginning of the 20th century.

\section{RESULTS}

The variations of glacier length $(\Delta L)$ and front elevation $(\Delta H)$ in the mountain regions under study are displayed in Table 1. On average, the mean (and median) values of glacier retreat in Siberia are less than in central Asia, on the Pacific coast (Koryakskoye Nagorye) and even in the Caucasus, where only the minimum estimates are given. In the histogram (Fig. 3) all glaciers are grouped in 45 classes according to the length they lost after the LIA maximum. Many Siberian

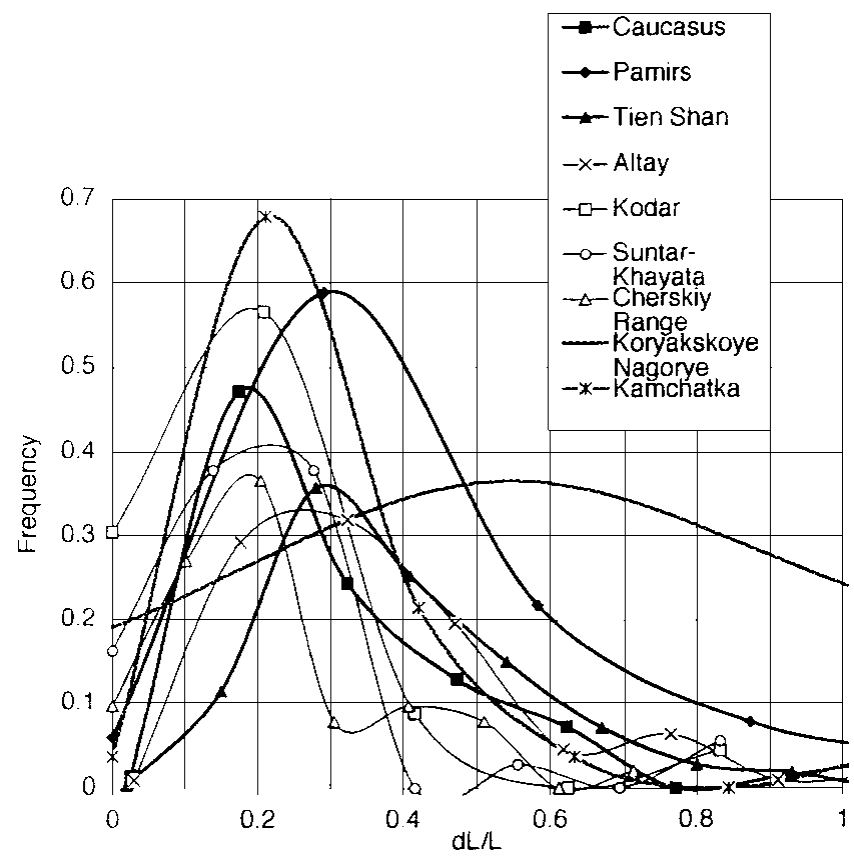

Fig. 4. Frequency distribution of relative length change $(\Delta L / L)$ of glaciers of various mountain areas in Eurasia since the LIA maximum (from the 17th to the middle of the 19th century). For the Caucasus the estimates are given for the period since the end of the 19th or the beginning of the 20th century. glaciers show minimum values of retreat, whereas those of $\mathrm{Pa}$ mir-Alay, Tien Shan and Koryakskoye Nagorye evidently lost much more. Since glaciers in central Asia and Koryakskoye Nagorye are larger than those in Siberia, this is quite apparent.

To focus on the effect of macroclimatic change we normalized the changes of the length $(\Delta L)$ by the length of the glacier $(L)$ (Fig. 4). In general, normalized length values do not show high inter-regional variation (except for Koryakskoye Nagorye), but the curves can still be subdivided into several groups by the peak of $\Delta L / L$ frequency. The group with the smallest retreat includes the east Siberian mountain ranges (Kodar, Suntar-Khayata, Cherskiy range), Kamchatka and the Caucasus. The relatively small retreat of Caucasus glaciers is related to the fact that in this region the position of moraines at the end of the 19th century instead of at the LIA maximum was analyzed (see previous section). The difference between glacier lengths at the end of the 19th century and between the 17 th and mid-19th centuries in the Caucasus is quite significant, amounting to several hundred meters (Serebryannyy and others, 1984). Kamchatka is the only region in the FSU where a positive mass balance was observed for the period 1957-85; some glaciers advanced or were stable at that time, so they lost less than glaciers in other regions (Mikhalenko and Solomina, 1996). The relative recession of glaciers is somewhat greater in Altay than in east Siberia. $\Delta L / L$ for Tien Shan and Pamir-Alay glaciers is higher and about the same for both regions (0.3). The most dramatic change occurred in Koryakskoye Nagorye where the peak is around $0.5-0.6$, in contrast to $0.2-0.3$ for all other regions, including the southernmost areas of central Asia. The variation of $\Delta L / L$ values in Koryakskoye Nagorye is very large, and the pattern of its frequency distribution differs from that in other regions, because more glaciers with high $\Delta L / L$ values occur in this region.

The same regional difference is evident in the distribution of front elevation shift which is several times higher in central Asian mountains and in Koryakskoye Nagorye (about 140$150 \mathrm{~m}$ ) than in Siberia (20, 40 and $60 \mathrm{~m}$ in Kodar, SuntarKhayata and the Cherskiy range, respectively) (Fig. 5; see also Table 1). Thus, the small, cold, rather passive glaciers existing in the severe continental climate of central Siberia appear to be much less variable than glaciers with high mass-energy transfer. Krenke and others (1991) arrived at a similar conclusion by comparing 19th-century maps of the Caucasus and modern ones. They found a positive correlation between equilibrium-line-altitude depression $(\Delta \mathrm{ELA})$ in the 19 th century and modern accumulation values.

\section{DISGUSSION}

Several potential sources of error should be commented on here.

1. Errors of moraine mapping and accuracy of measurements. The accuracy is rather low for the LIA scale of glacier variations. However, even if we take the maximum error $( \pm 50 \mathrm{~m})$, the difference between the two groups of regions (internal Siberia and others) is evident for both $\Delta L / L$ and $\Delta H$ variables.

2. Errors associated with surging glaciers. Surging glaciers in Pamir-Alay retreated twice as much as non-surging ones (see Table 1), but this difference is affected by the surging-glacier size included in the sample: the average length of surging glaciers is about $6500 \mathrm{~m}$, whereas the 


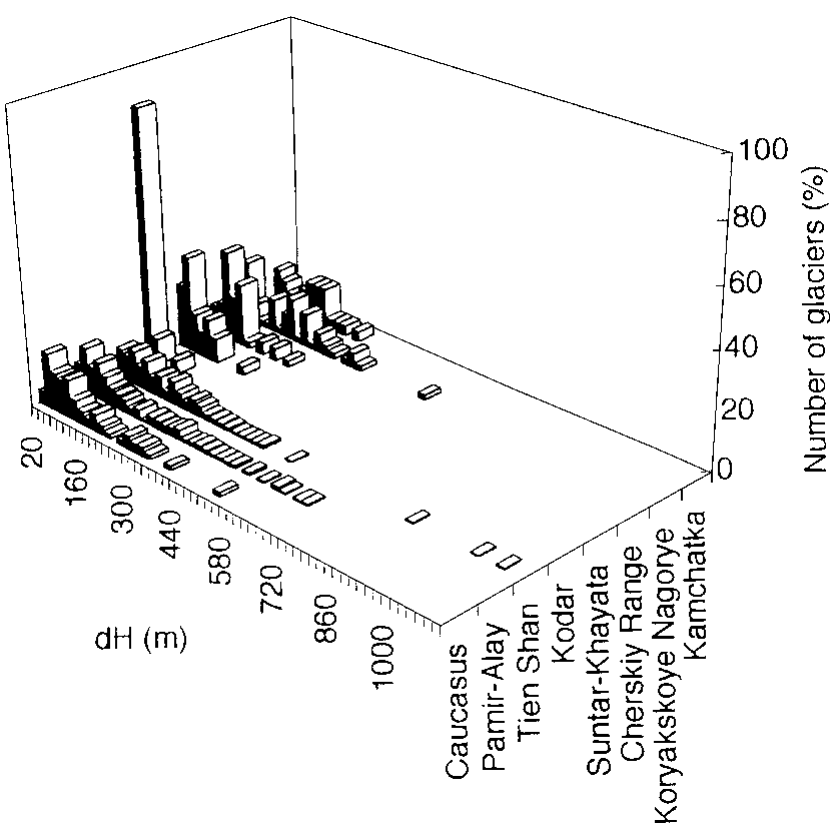

Fig. 5. Front elevation change $(\Delta H)$ of glaciers since the LIA maximum (from the 17th to the mid-19th century). For the Caucasus the front elevation changes are estimated since the end of the 19th or the beginning of the 20th century.

length of non-surging glaciers is $3500 \mathrm{~m}$. The $\Delta L / L$ values are similar for both surging $(0.30)$ and non-surging (0.32) glaciers.

3. Errors of moraine dating. The possibility of including moraines that predate or postdate the LIA is not ruled out due to the spatial variations and temporal discontinuities of plant colonization. However, recognition of vegetation differences and other methods based on vegetation and soil characteristics "are capable of yielding a crude identification of terrain age" (Matthews, 1992) that is sufficient to define the temporal boundaries (LIA) accepted here. Lichenometry used in different regions in combination with plant-succession descriptions provides some control on the regularity of the development of local chronosequences, and the great number of glaciers included in the analysis diminishes the weight of the errors in the average values.

The concept of the LIA itself requires some comment in light of the suggestion that "there is no evidence for a world-wide, 300-400 year long, synchronous cold interval, affecting all seasons, to which we can ascribe the term 'Little Ice Age" (Bradley and Jones, 1992). We do not discuss this question in detail here, but the fact that geomorphic evidence of several glacier advances in recent centuries (see Fig. 2) is found and dated in many regions allows us to use the term LIA in a general sense and to constrain it, according to lichenometry, to the 16 th-19th centuries: this time interval coincides with that cited by Bradley and Jones (1992) as $1510 \pm 50 / 1850 \pm 50$.

The estimates of front elevation enable us to roughly assess the shift of the equilibrium-line altitude (as one-half of the front depression) and to compare it with that in other regions. This method is normally considered imprecise (Torsnes and others, 1993), but being very simple, it is of great utility, especially in the case of large samples. Maisch (1992) compared the directly measured $\triangle \mathrm{ELA}$ in AD 1850
$(77 \mathrm{~m})$ with the front depression calculated for 684 Alpine glaciers $(165 \mathrm{~m})$. He concluded that half of this value is about the same as the measured $\triangle \mathrm{ELA}$. The $\triangle \mathrm{ELA}$ estimation in the Pamir-Alay, Tien Shan and Koriakskoye Nagoriye (60$70 \mathrm{~m}$ ) is similar to Maisch's $\Delta$ ELA estimate for the Alps. The same $\triangle \mathrm{ELA}(70 \mathrm{~m})$ was cited for western Norway (Torsnes and others, 1993). The $\triangle \mathrm{ELA}$ in the central Caucasus between the end of the 19th and the beginning of the 20th century is about $60 \mathrm{~m}$. Golodkovskaya estimates the $\triangle$ ELA as $50-60 \mathrm{~m}$ for the end of the 19 th century and about $75 \mathrm{~m}$ for the mid-19th century (Serebryannyy and others, 1984). Panov (1993) reported about a $90 \mathrm{~m} \Delta \mathrm{ELA}$ for the whole Caucasus at the end of the 19th century. The $\triangle \mathrm{ELA}$ in east Siberia, according to our rough estimations, is much smaller, within the range $20-40 \mathrm{~m}$.

For the temperate zone of the Northern Hemisphere in general, Porter (1970) estimates that the LIA $\triangle$ ELA is about 100-150 m, but some authors consider that the variance recorded in $\triangle \mathrm{ELA}$ in different regions is significant (Gross and others, 1977; Maisch, 1992; Solomina, 1997). This paper supports this last point of view since we can distinguish at least maritime and continental areas by the magnitude of glacier shrinkage.

\section{GONGLUSIONS}

Given the limitations imposed by the materials available, we must content ourselves here with analyzing very broad time-scales for glacier changes from the LIA maximum up to the $1950 \mathrm{~s}-80 \mathrm{~s}$.

According to lichenometry, in most mountain regions of the FSU the LIA maximum occurred between the end of the 17 th and the first half of the 19th century; these dates are indirectly supported by tree-ring data.

The magnitude of glacier variations in mountain regions of the FSU since the LIA maximum is variable. The glaciers of this area can be grouped into two categories: one includes the glaciers located along the southern border of the FSU and on the eastern periphery of Asia, in Koryakskoye Nagorye; the second comprises the glaciers of continental Siberia: in Kodar, Suntar-Khayata and the Cherskiy range.

In general, the magnitude of glacier shrinkage is much larger for mountain glaciers in central Asia than in northeast Siberia, but it increases again further east, at the Pacific rim of the continent, in Koriakskoye Nagoriye.

\section{ACKNOWLEDGEMENTS}

Most of the work with maps and aerial photographs was done in association with my colleagues. I sincerely thank M. I. Bodnya, G. M. Varnakova, T. N. Pokrovskaya, E. S. Filatov, Ya. D. Murav'yev and V. N. Mikhalenko, who participated in this project. Due to the kind assistance of V. S. Kuz'michenok, we managed to obtain the most detailed cartographic data for Tien Shan; R. Barry, A. F. Glazovsky, and S. M. Arkhipov made valuable comments on the manuscript. I am very grateful for valuable comments by the scientific editor G. H. Gudmundsson, R.S.W. van de Wal and an anonymous reviewer. The compilation of the inventory was supported by a research grant from the International Science Foundation (J. Soros Foundation). The preparation of the manuscript was supported by the Russian Fund for Basic Research (grant No. N99-05-64946). 


\section{REFERENCES}

Akademii Nauk SSSR. 1969-82. Katalog lednikov SSSR [ Inventory of glaciers of the USSR]. Vols 1-20. Leningrad, Gidrometeoizdat.

Bradley, R. S. and P. D. Jones. 1992. When was the "Little Ice Age"? In Mikami, T., ed. International Symposium on the Little Ice Age Climate, 25-28 September 1991, Tokyo. Proceedings. Tokyo, Tokyo Metropolitan University. Department of Geography, 1-4.

Furrer, G., G. Burga, M. Gamper, H. Holzhauser and M. Maisch. 1987. Zur Gletscher-, Vegetations- und Klimageschichte der Schweiz seit der Späteiszeit. Geogr. Helv., 42(2), 61-91.

Gross, G. 1987. Der Flächenverlust der Gletscher in Österreich 1850-19201969. Z. Gletscherkd. Glazialgeol., 23(2), 131-141.

Gross, G., H. Kerschner and G. Patzelt. 1977. Methodische Untersuchungen über die Schneegrenze in alpinen Gletschergebieten. Z. Gletscherkd. Glazialgeol., 12(2), 1976, 223-251.

Grove, J. M. 1988. The Little Ice Age. London, Methuen and Co. Ltd.

Koreysha, M. M. 1991. Oledeneniye Verkhoyansko-Kolymskoy oblasti [ Glaciation of the Verkhoyansk-Kolyma region]. Moscow, Izdatel'stvo Nauka. Akademiia Nauk SSSR. Mezhduvedomstvennyi Geofizicheskii Komitet. Rezul'taty Issledovaniy po Mezhdunarodnym Geofizicheskim Proyektam.

Korzhenevskiy, N. L. 1930. Katalog lednikov srednei Azii _Glacier catalog of central Asia]. Tashkent, Aziatskii Meteorologicheskii Institut. Gidrometeorologicheskii Otdel. (Sredne.)

Krenke, A. N., G. M. Nikolayeva and A. B. Shmakin. 1991. The effects of natural and anthropogenic changes on heat and water budgets in the central Caucasus. Mt. Res. Dev., 11 (3), 173-182.

Maisch, M. 1992. Die Gletscher Graubündens: Rekonstruktionen und Auswertung der Gletscher und deren Veränderungen seit dem Hochstand von $1850 \mathrm{im}$ Gebiet der östlichen Schweizer Alpen (Bündnerland und angrenzende Regionen). Zürich, Universität Zürich. Geographisches Institut. (Physische Geographie 33.)

Matthews, J. A. 1992. The ecology of recently-deglaciated terrain. A geoecological approach to glacier forelands and primary succession. Cambridge, Cambridge University Press.

Mikhalenko, V. and O. Solomina. 1996. Long-term variations of mountain glaciers in the former USSR (FSU). Part 1. Mass balance reconstructions. Z. Gletscherkd. Glazialgeol., 32, Part 2, 1995, 159-166.

Panov, V. D. 1993. Evoliutsiya sovremennogo oledeneniya Kavkaza [Evolution of modern glaciation of the Caucasus]. St Petersburg, Gidrometeoizdat.

Podozersky, K. I. 1911. Ledniki Kavkazskogo Khrebta [Glaciers of the Caucasus Range]. Zapiski Kavkazskogo Otdeleniya Russkogo Geograficheskogo Obchestva [Proceedings of the Caucasian Branch of the Russian Geographical Society ], 29(1), 1-200.

Porter, S. C. 1970. Quaternary glacial record in Swat Kohistan, west Pakistan. Geol. Soc. Am. Bull., 81 (5), 1421-1446.

Preobrazhenskiy, V.S. 1960. Kodarskiy lednikovyy rayon (Zabaykal'ya) [The Kodarsky glacier region (Transbaikal)]. Akad. Nauk SSSR. Mezhd. Kom., Ser. IX. Razdel Programmy MGG (Glyatsiologiya) 4.

Revyakin, V.S. and R. M. Mukhametov. 1986. Dinamika lednikov AltaveSayanskoy gornoy sistemy za 150 let / Glacier dynamics in the Altay-Sayan mountain system for the last 150 years. Mater. Glyatsiol. Issled. 57, 95-99 (Russian); 214-216 (English).

Sapozhnikov, V.V. 1926. Puti po Russkomu Altayu [Travels in Russian Alay]. Tomsk, Sibkraiiszat.

Schweingruber, F. H. and K. R. Briffa. 1996. Tree-ring density network for climate reconstructions. In Jones, P. D., R. S. Bradley and J. Jouzel, eds. Climatic variations and forcing mechanisms of the last 2000 years. Berlin, etc., Springer-Verlag, 43-66. (NATO ASI Series I: Global Environmental Change 41.)

Serebryannyy, L. R., N. A. Golodkovskaya, A.V. Orlov, E. S. Malyasova and E. O. Il'ves. 1984. Kolebaniya lednikov i protsessi morenonakopleniya na Tsentral'nomkavkaze [Glacier variations and moraine accumulation: processes in central Caucasus ]. Moscow, Nauka.

Solomina, O. N. 1997. Gornoye oledeneniye servernoy Evrazii v golotsene [Mountain glaciers of northern Eurasia in the Holocene]. (Ph.D. thesis, Moscow, Russian Academy of Sciences. Institute of Geography.)

Torsnes, I., N. Rye and A. Nesje. 1993. Modern and Little Ice Age equilibrium-line altitudes on outlet valley glaciers from Jostedalsbreen, western Norway: an evaluation of different approaches to their calculation. Arct. Alp. Res., 25(2), 106-116. 